DOI

\title{
ЕКСТРАКОРПОРАЛЬНА УДАРНО-ХВИЛЬОВА ТЕРАПІЯ: ІСТОРИЧНІ АСПЕКТИ РОЗВИТКУ ТА ЗАСТОСУВАННЯ У СУЧАСНІЙ МЕДИЧНІЙ ПРАКТИЦІ (ОГЛЯД ЛІТЕРАТУРИ)
}

\author{
๑Ю. М. Мельничук, Р. З. Огоновський
}

Львівський національний медичний університет імені Данила Галицького

РЕЗЮМЕ. Проведено ретроспективний аналіз та узагальнення літературних повідомлень щодо історії виникнення, розвитку та застосування екстракорпоральної ударно-хвильової терапії у сучасній медичній практиці, суть методики застосування ударної хвилі, визначено основні показання та протипоказання до застосування.

КЛЮчОВІ СЛОВА: екстракорпоральна ударно-хвильова терапія, ударна хвиля, генератори хвиль.

Вступ. У сучасній клінічній медицині все частіше застосовується методика ударно-хвильової терапії в різних галузях і спеціальностях. Безпечність, малоінвазивність, легкість у експлуатації та позитивні результати застосування дозволяють вважати її одним із найперспективніших та найактуальніших векторів розвитку фізіотерапевтичних методів лікування, що буде застосовуватися у травматології, ортопедії, дерматології та загальній хірургії. Надзвичайно цікавою та багатообіцяючою $\epsilon$ можливість використання енергії ударних хвиль для профілактики та лікування патологічних рубців шкіри, які можуть формуватися після оперативних втручань та опіків.

Мета дослідження. Провести аналіз літературних джерел щодо методики екстракорпоральної ударно-хвильової терапії.

Основна частина. Екстракорпоральна ударнохвильова терапія (ЕУХT) - це новітня неінвазивна методика, яка використовується у багатьох галузях медицини. Вона полягає у генерації високочастотних хвиль, які впливають безпосередньо на тканини організму людини.

Метод екстракорпоральної ударно-хвильової терапії бере початок з 40-х років XX ст. Безсумнівна першість у винаході генератора ударних хвиль належить Frank Rieber, а отже, йому і належить винахід самих ударних хвиль. Цей факт підтверджений американським патентом N 2.559.227 від 3 липня 1951 року, в якому автор використовував електрогідравлічний принцип генерації ударних хвиль з подальшою передачею їх в тканини людського організму (рис. 1). Апарат застосовували для лікування пухлин головного мозку. Але значного поширення ця методика не отримала, і до неї повернулися лише у другій половині двадцятого століття [1, 2].

У середині і наприкінці 70-х років $€$. Eisenberger, К. Чаусско і Форсман (син нобелівського лауреата, уролог) проводили експериментальні дослідження літотриптора, під час яких працюва- ли з собаками, яким імплантували людські камені в нирки [3].

У 1980 р. в Мюнхені за допомогою ударнохвильових імпульсів було зруйновано камінь в нирці людини, і з цього часу спосіб використовують як «золотий стандарт» терапії сечокам'яної хвороби, а з 1985 року ударно-хвильову літотрипсію також застосовують для дроблення каменів у жовчному міхурі людини.

В експериментах на тваринах було виявлено, що при зменшенні тиску і щільності енергетичного потоку імпульсу знижувалася його руйнівна здатність і проявлялася протизапальна, знеболювальна та стимулювальна дія на тканини. Результати досліджень показали, що після застосування ЕУХТ немає ознак ушкодження м'яких тканин. У досліджуваних тварин превалювали процеси переважно продуктивного характеру, на тлі помірного повнокрів'я судин без ознак ушкодження їх стінки та колагенових волокон, частина з них набувала вигляду фібробластів [3-6].

З огляду на виявлені в останнє десятиліття XX ст. ефекти, ЕУХТ стали використовувати в травматології, ортопедії, неврології та естетичній хірургії. 3 початку дев'яностих років в травматологічній практиці для лікування пошкоджень кісток і м'яких тканин почали використовувати метод ударно- хвильового впливу [7-9].

Ще в сорокових роках минулого століття основоположник вітчизняної ортопедії Г. І. Турнер рекомендував постукувати місце перелому при лікуванні несправжніх суглобів дерев'яним молоточком.

На пострадянському просторі перше повідомлення про застосування ЕУХТ було зроблене в Росії у 1999 році. Методика була застосована у 87 хворих з захворюваннями сухожиль і капсулярнозв'язкових структур, що кріпилися до кісток [9].

На відміну від багатьох інших використовуваних в медицині акустичних хвиль, ударні хвилі не мають пульсуючого характеру. Вплив безперервних хвиль високої частоти проявляється, в першу 
Огляди літератури, оригінальні дослідження, погляд на проблему

чергу, генерацією тепла в тканинах. Цей ефект використовують з терапевтичною метою. Для запобігання надмірному нагріванню інтенсивність звуку обмежується невеликим значенням (3 Вт / см). Відомо, що ударні хвилі являють собою змінні коливання тиску, які розповсюджуються в просторі і при яких впродовж дуже короткого часу тиск підвищується. У більшості медичних апаратів максимум тиску досягається впродовж декількох наносекунд. Разом із стрімко зростаючим імпульсом тиску, ударні хвилі мають від'ємну різницю тиску і приєднують фазу розрідження, яка супроводжується падінням тиску нижче рівня оточуючого середовища. Вважають, що ударні хвилі характеризуються позитивним максимальним тиском (Pt) і негативним максимальним тиском (Pt).

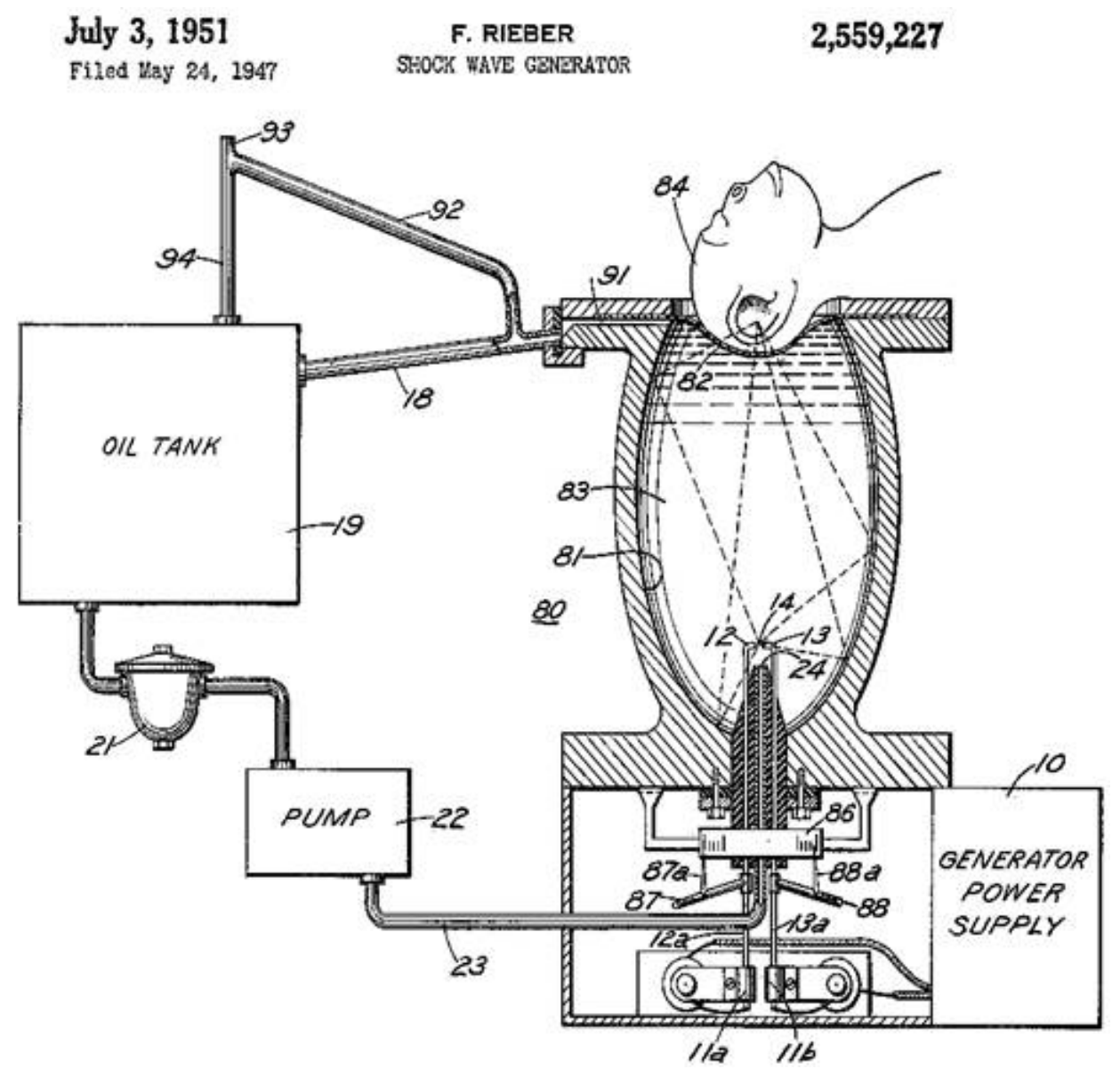

Рис. 1. Перша модель генератора хвиль Ф. Рейбера.

При ударно-хвильовому впливі імпульс, який виробляється генератором, перетворюється в звукову хвилю і передається у зовнішнє середовище. Акустична хвиля поширюється в тілі людини, яке на 65-80 \% складається з води, і поглинається на межі з кісткою, при цьому потужність впливу залежить від різниці щільності тканин. Метою генерації хвилі $\epsilon$ спроектоване направлення ударної хвилі в тканини з найменшими втратами енергії. Потік енергії прискорюється завдяки стиснутому повітрю, а потім з високою кінетичною енергією попадає на аплікатор [10].

При високоінтенсивному режимі акустичні хвилі високого тиску викликають послідовне стиснення і розтягування тканин з перепадом тиску, що призводить до утворення «кавітаційних бульбашок». На піку тиску розмір бульбашок мінімальний і досягає максимуму в період розрідження. Під час максимального спаду тиску «кавітаційні бульбашки» тріскаються, що призводить до вивільнення великої кількості енергії. Найбільший ефект від дії ударних хвиль відбувається в більш щільних тканинах і на межі розділу тканин: кістка-сухожилля, м'яз-фасція, фасція-шкіра і т.д. Ударно-хвильові імпульси не викликають локальних порушень в тканинах та не здійснюють системних патологічних впливів на організм в цілому, тому можливість застосовувати ударно-хвильову терапію на шкірні покриви для впливу на патологічні процеси, що відбуваються у ній, викликає інтерес у фахівців.

Ударна хвиля, «розпушуючи» тканини, стимулює процеси репарації та покращує мікроциркуляцію в кровоносних судинах м'яких та твердих тканин [3]. 
Огляди літератури, оригінальні дослідження, погляд на проблему

Експерименти на тваринах засвідчили, що застосування ЕУХТ може стимулювати маркери, які відповідають за ангіогенез, і сприяти неоваскуляризації, що, в свою чергу, може покращити кровопостачання і регенерацію тканин [11].

Однією 3 найважливіших особливостей дії ударної хвилі $\epsilon$ стимуляція мікроциркуляції, тобто кровообігу, що позначається на стані трофічних процесів у тканинах. Згідно з сучасними уявленнями, під поняттям «мікроциркуляція» розуміють не тільки рух рідини судинним руслом, а й поза ним. Мікроциркуляція забезпечує обмін речовин у тканинній мікросистемі, до якої входять клітини, специфічні для даної тканини, сполучнотканинні утворення і фізіологічно активні речовини. Вона відбувається безпосередньо у мікроциркуляторному руслі, яке можна розглядати як систему, що складається з трьох ланок: кровоносної, лімфатичної і міжклітинної. Унаслідок покращення мікроциркуляції визначаються чітко виражений протинабряковий ефект, зменшення напруження тканин, що викликає регенераторну, імуномодулювальну, протизапальну, десенсибілізувальну дії.

В результаті лікування значно зменшуються або зникають болі, відновлюється цілісність кісткової тканини, підвищується еластичність шкіри $[1,12,13]$.

При застосуванні УХТ відбувається зниження больових відчуттів до повного їх зникнення. Механізм знеболювальної дії пояснюється тим, що в ділянці проходження ударних хвиль змінюється рівень вмісту субстанції Р, яка $\epsilon$ нейротрансміттером болю $[14,15]$.

ЕУХТ чинить позитивний вплив при терапії дегенеративно-дистрофічних захворювань, травм опорно-рухового апарату та їх ускладнень у 70-80 \% випадків. Регулярне застосування ЕУХT при даних патологічних процесах в значній мірі дозволяє запобігти оперативному втручанню [2, 3, 16-21]. Ефект після проведення процедур проявляється через декілька тижнів після лікування. Курс лікування складає 3-7 процедур з інтервалом в 5-7 днів.

Основою терапевтичного ефекту акустичних хвиль високого тиску $є$ :

- посилення метаболізму в місці дії;

- поліпшення кровопостачання, кровообігу i регенерації нових судин у зоні впливу;

- зменшення активності запальних процесів (хронічне запалення перетворюється в гостре, яке розпізнається та долається організмом самостійно);

- збільшення дифузії цитокінів через стінки судин, що прискорює процес одужання;

- вихід ендорфінів, що знижують місцеву чутливість до болю;
- стимуляція доцентрових нервових волокон периферійних шкірних нервів, які активують анальгетичні механізми в задніх рогах спинного мозку;

- часткове руйнування мембран в клітинах кісткової тканини (при цьому вивільняються кальційвмісні сполуки, що спричиняють мікрокрововиливи, які $\epsilon$ пластичним матеріалом в формуванні кісткової мозолі при переломах).

У хворих підвищується переносимість навантажень, що призводить до розриву патологічно кола: травма $\rightarrow$ гіпоксія $\rightarrow$ запалення $\rightarrow$ біль $\rightarrow$ о6меження рухів $[22,23]$.

Ударно-хвильова терапія має ряд переваг перед традиційними методами лікування:

- лікування проводиться в амбулаторних умовах та не порушує звичний ритм життя;

- відсутні побічні явища;

- лікування проходить впродовж короткого часу (тривалість однієї процедури 20-30 хв) з швидким досягненням довготривалого терапевтичного ефекту;

- добре переноситься і не потребує знеболювання;

- у багатьох випадках дозволяє уникнути проведення оперативного втручання.

Протипоказаннями до застосування ударнохвильової терапії $є$ :

-онкологічні захворювання. Злоякісні новоутворення $\epsilon$ протипоказаннями, адже ударно-хвильова терапія може сприяти метастазуванню процесу;

- порушення згортання крові, як і прийом антикоагулянтів, може призвести до крововиливів у м'які тканини;

- інфекційні захворювання;

- вагітність;

- цукровий діабет;

- переломи ключиці і ребер;

- загострення серцево-судинних захворювань. У пацієнтів з гіпертонічною хворобою необхідний контроль артеріального тиску, так як ЕУХТ може викликати гіпертонічний криз. Артеріальний тиск рекомендовано вимірювати до i після сеансу лікування;

- наявність штучного водія ритму серця;

- епіфізарні ділянки у дітей.

В експериментах на тваринах доведена можливість пошкодження зони росту кісток, при цьому відмічалися випадки як затримки, так і прискорення їх росту [24].

Практично всі генератори ударних хвиль складаються з електричного джерела енергії, електроакустичного перетворювача і пристрою фокусування ударних хвиль.

Однак перераховані системи мали виражені недоліки, що обмежували їхнє застосування у медичній практиці: 
Огляди літератури, оригінальні дослідження, погляд на проблему

Типи приладів для ударно-хвильової терапії $[8,16,25]$ :

\begin{tabular}{|c|c|c|}
\hline Рік заснування & Тип приладу & Принцип дії \\
\hline 1980 & $\begin{array}{l}\text { Електрогідравлічний генератор } 3 \\
\text { еліпсоїдним поширенням хвилі }\end{array}$ & $\begin{array}{l}\text { Акустична хвиля створюється у рідкому середовищі } \\
\text { за допомогою електричного розряду (принцип свічки } \\
\text { запалювання) }\end{array}$ \\
\hline 1985 & $\begin{array}{l}\text { П'єзоелектричний генератор } \\
\text { з поширенням хвилі у вигляді } \\
\text { сфери }\end{array}$ & $\begin{array}{l}\text { Високовольтний імпульс викликає розширення } \\
\text { п'єзокристалів, розташованих на пароболічній поверхні }\end{array}$ \\
\hline 1986 & $\begin{array}{l}\text { Електромагнітний генератор } 3 \\
\text { акустичною лінзою }\end{array}$ & $\begin{array}{l}\text { Високовольтний розряд через котушку (циліндричну } \\
\text { або пласку) викликає вихровий струм у розташованій } \\
\text { поруч мембрані і відхиляє її відповідно до } \\
\text { електромагнітного принципу }\end{array}$ \\
\hline 1989 & $\begin{array}{l}\text { Електромагнітне циліндричне } \\
\text { джерело хвиль }\end{array}$ & Параболоїдне поширення ударних хвиль \\
\hline 2001 & Пневматичний генератор & $\begin{array}{l}\text { Ударні хвилі генеруються поза тілом пневматичним } \\
\text { джерелом, потім перетворюються і фокусуються в } \\
\text { маніпуляторі у звукові хвилі }\end{array}$ \\
\hline
\end{tabular}

- недостатньо тривалий термін служби;

- невеликий розмір фокусу;

- високі витрати на технічне обслуговування;

- надмірно високу енергію впливу;

- незручність позиціонування фокусу ударної хвилі при лікуванні патології передпліччя і плечового суглоба;

- обов'язкове використання рентген- і УЗДнаведення.

Всі ці недоліки привели до обмеження використання вказаних апаратів в клінічній практиці. Враховуючи недоліки наявної апаратури були розроблені модульні пристрої, що дозволяють генерувати імпульси, необхідні для застосування в травматологічній та ортопедичній практиці. Були створені апарати з балістичним принципом дії.

їх перевагою є:

- малі габарити, що дозволяють проводити лікування як стаціонарно, так і в амбулаторній практиці;

- зручний пневматичний маніпулятор, який дає можливість безпосередньо встановлювати його на шкіру під потрібним кутом впливу;

- радіальна розфокусована ударна хвиля середньо- і низькоенергетичного впливу, що дозволяє проводити маніпуляції без рентгенівського і УзД- наведення, методом «біозворотного зв'язку».

Останніми перспективами в застосуванні ударних хвиль були проведені в Німеччині дослідження, які вивчали зрощення переломів уповільненої консолідації та синдром «замороженого плеча» $[7,13,26]$, а також можливість використан- ня ЕУХТ для корекції після опікових деформацій шкіри [27-29], що становить значний науковий інтерес.

Використання даної апаратури, адаптованої для травматологічної, хірургічної та косметологічної практик, дозволило розширити показання до застосування ЕУВТ при лікуванні травматичних ушкоджень і дегенеративних захворювань опорно-рухової системи, патологічних деформацій шкіри.

Останні гістологічні, біохімічні та імунологічні дослідження суттєво покращили наше уявлення про вплив ударних хвиль на тканини, оброблені ЕУХТ. До них належать підвищена васкуляризація, прискорене виділення факторів росту, вибіркове невральне інгібування, рекрутування стовбурових клітин та молекул, що відіграють певну роль у запальному процесі.

Висновки. В літературі представлені поодинокі публікації, присвячені застосуванню ЕУХТ в сучасній клінічній практиці, та недостатньо досліджені більш широкі можливості застосування в практичній медицині, зокрема, про застосування ударних хвиль для впливу на різноманітні дерматологічні патології, такі як патологічні рубці шкіри. Особливо мало літературних згадок про застосування даного методу в стоматології, а саме в хірургічній стоматології та щелепно-лицевій хірургії.

Перспективи подальших досліджень полягають у вивченні застосування екстракорпоральної ударно-хвильової терапії для корекції та профілактики патологічних рубців шкіри обличчя. 
Огляди літератури, оригінальні дослідження, погляд на проблему

\section{ЛІТЕРАТУРА}

1. Shock wave application enhances pertussis toxin protein-sensitive bone formation of segmental femoral defect in rats. / Y. J. Chen, Y. R. Kuo, K. D. Yang [et. al.] // J. Bone. Miner. Res. - 2003. - Vol. 18. - P. 2169-2179.

2. Арнольд А. Экстракорпоральная ударно-волновая (ESWT) терапия и ультразвуковое исследование опорно-двигательного аппарата / А. Арнольд, Х. Е. Бахманн, Г. Грубер - М., 1998. - С. 9-16.

3. Extracorporeal shock wave therapy of nonunion or delayed osseous union / W. Schaden, A. Fischer, A. Sailler [et al.] // Clin. Orthop. Relat. Res. - 2001. - Vol. 38, № 7. - P. 90-94.

4. Palmieri A. A first prospective, randomized, doubleblind, placebo-controlled clinical trial evaluating extracorporeal shock wave therapy (ESWT) for the treatment of peyronie`s disease (PD) / A. Palmieri // Europ. Urol. 2009. - Vol. 56, № 2. - P. 363-370.

5. Вплив екстракорпоральної ударно-хвильової терапії на сухожилкову тканину (експериментальне дослідження) / В. М. Левенець, М. Б. Циганок, О. В. Сергієнко, Б. І. Паламарчук // Спортивна медицина. - 2012. № 2. - С. 107-112.

6. Островський О. А. Зміни в клітинах і тканинах живих організмів під впливом ударно-хвильової терапії (огляд спеціальної літератури) / О. А. Островський // Спортивна медицина. - 2013. - № 1. - С. 7-11.

7. Effect of extracorporeal shock waves on subcondylar mandibular fractures. / E. E. Altuntaş, Z. Oztemur, H. Ozer, S. Müderris // J. Craniofac. Surg. - 2012. - Vol. 23, № 6. - P. 1645-1648.

8. Chen Y. J. Extracorporeal shock waves promote healing of collagenase induced Achilles tendinitis and increase TGF-beta1 and IGF-I expression. /Y. J. Chen, C. J. Wang, K. D. Yang // J. Orthop. Res. - 2004. - Vol. 2. - P. 854-861.

9. Миронов С. П. Применение экстракорпоральной ударно-волновой терапии при лечении хронических дегенеративно-дистрофических заболеваний опорнодвигательной системи / С. П. Миронов, Д. О. Васильев, Г. М. Бурмакова // Вестник травматологии и ортопедии. - 1999. - № 1. - С. 6-29.

10. Левенец В. Н. История экстракорпоральной ударно-волновой терапии в лечении дегенеративнодистрофических заболеваний опорно-двигательной системи / В. Н. Левенец, М. М. Риган, М. Б. Цыганок // Спортивна медицина. - 2009.- № 1-2. - С. 137-148.

11. Haake $M$. Absence of spinal response to extracorporeal shock waves on the endogenous opioid sustem in the rat/M. Haake, A. Thon, M. Bette//Ultrasound. Med. and Biology. - 2001. - № 27. - P. 220-232.

12. Kudo P. Randomized, placebo-controlled, doubleblind clinical trial evaluating the treatment of plantar fasciitis with an extracorporeal shockwave therapy (ESWT) device: a North American confirmatory study / P. Kudo, K. Dainty, M. Clarfield // J. Orthop. Res. - 2006. - Vol. 24. P. 115-123.

13. Leal C. Shockwave Medicine Past, Present and Future / C. Leal // Shockwave society for medicals shockwave treatment. - 2012. - Vol. 8. - P. 2-3.

14. Бодня Н.И. Опыт применения ударно-волновой терапии в лечении миофасциальних болевых синдро- мов / Н. И. Бодня, В. Н. Проценко, В. Г. Морихин // Мануальная терапия. - 2013. - № 3. - С. 76-78.

15. Шель Я. Современное представление о фокусированной и радиальной терапии / Я. Шель // Спортивна медицина. - 2013. - № 1. - С. 3-6.

16. Lai J. P. Extracorporeal shock wave accelerates consolidation in distraction osteogenesis of the rat mandible / J. P. Lai, F. S. Wang, C. M. Hung // J. Trauma. - 2010. Vol. 69, № 5. - P. 1252-1258.

17. Rompe J.-D. Extracorporeal shock wave therapy for the calcifying tendinitis of the shoulder / J.-D. Rompe // Clinical. Orthopedy. - 1995. - Vol. 32, № 1. - P. 196 -201.

18. Schaden W. Shock wave therapy for acute and chronic soft tissue wounds: a feasibility study / W. Schaden, R. Thiele, C. Kölpl // J. Surg. Res. - 2007. - Vol. 14, № 3. P. 1-12.

19. Zimmermann R. Shockwave therapy for the treatment of chonic pelvic pain syndrome in males: a randomized, double- blind, placebo - controlled study / R. Zimmermann // Europ. Urol. - 2009. - Vol. 56, № 3. - P. 418-424.

20. Досвід лікування епікондилітів плечової кістки із застосуванням екстракорпоральної ударно-хвильової терапії / В. І. Медзин, В. Т. Сенник, Д. В. Лось [та ін.] // Проблеми військової охорони здоров'я:зб. наук. праць Укр. Військово-мед. акад. - К., 2012. - Вип. 34, Т. 2. C. 192-197.

21. Особенности лечения переломов и ложных суставов ладьевидной кости у спортсменов / А. В. Борзых, И. А. Соловьев, И. М. Труфанов, С. В. Попов // Спортивна медицина. - 2013. - № 1. - С. 29-32.

22. Использование экстракорпоральной ударноволновой терапии в лечении хронического болевого синдрома / А. В. Ивченко, В. Н. Коротнев, В. А. Родичкин [и др.] // Спортивна медицина. - 2013. - № 1. C. 26-28.

23. Левенець В. М. Ударно-хвильова терапія в лікуванні несправжніх суглобів / В. М. Левенець, М. М. Риган, А. О. Веремій // Спортивна медицина. - 2013. - № 1. C. 17-21.

24. Шель Я. Экстракорпоральная ударно-волновая терапияпритравмахизаболеванияхопорно-двигательного аппарата спортсменов / Я. Шель, С. Арентц, Г. Лорер // Спортивна медицина. - 2010. - № 1-2. - С. 37-46.

25. Екстракорпоральна ударно-хвильова терапія як метод неінвазивного лікування ентезопатій / В. М. Чорний, М. Л. Головаха, В. Ю. Юрків, В. Г. Маріхін // Спортивна медицина. - 2013. - № 1. - С. 22-25.

26. Ekkernkamp A. Extracorporeal shock waves in orthopeadics / A. Ekkernkamp, G. Haupt // J. Urol. - 1991. Vol. 145. - P. 257.

27. Extracorporeal shock waves improve angiogenesis after full thickness burn / O. Goertz, H. Lauer, T. Hirsch [et. al.] // Burns. - 2012. - Vol. 38, № 7. - P. 1010-1018.

28. Extracorporeal shock wave therapy for the management of burn scars / P. Fioramonti, E. Cigna, M. G. Onesti [et. al.] // Dermatol. Surg. - 2012. - Vol. 38, № 5. - P. 778-782.

29. Extracorporeal shock waves, a new non-surgical method to treat severe burns / A. Arnó, O. García, I. Hernán // Burns. - 2010. - Vol. 36, № 6. - P. 844-849. 

AND APPLICATION OF MODERN MEDICAL PRACTICE (REVIEW)

@Yu. M. Melnychuk, R. Z. Ohonovskyi

Lviv National Medical University by Danylo Halytskyi

SUMMARY. The article adduces a retrospective analysis and synthesis of literature on the history of communications, development and application of extracorporeal shock-wave therapy in modern medical practice, the essence of the method of application of the shock wave, the main indications and contraindications for use.

KEY WORDS: extracorporeal shock-wave therapy, shock wave, wave generators. 